\title{
FABRICATION OF COPPER META-MATERIAL THROUGH METALLURGICAL TECHNIQUE AND ITS ADVANCED APPLICATIONS
}

\author{
K.Sunil Babu ${ }^{1}$, K.Umakantham ${ }^{2}$, V.Prasanthi ${ }^{3}$, D.Kishore Kumar ${ }^{4}$ \\ ${ }^{I}$ Department of Physics, Pydah Kaushik College of Engineering, Visakhapatnam, A.P, India \\ ${ }^{2}$ Department of Physics, Pydah Kaushik College of Engineering, Visakhapatnam, A.P, India \\ ${ }^{3}$ Department of Physics, Pydah College of Engineering, Visakhapatnam, A.P., India \\ ${ }^{4}$ Department of Mechanical Engineering, Pydah Kaushik College of Engineering, Visakhapatnam, A.P, India
}

\begin{abstract}
Nano Copper has been synthesized by using ancient metallurgical technique from copper sulphate. The stability of nano copper is monitored by a Thorough a systematic analysis.

The copper meta-material was synthesized at different heat treatment processes ranging from heating 1 to 8 . This process has been developed to optimize accurate fabrication of nano copper. Characterization has been done by XRD and SEM. In the development of nano size materials of metal and metal oxides particles are intensively pursued because of their prominence in different fields of applications in science \& technology.
\end{abstract}

Various physical parameters like purity of copper, melting point, density, hardness, electrical conductivity etc have been measured using suitable techniques. In the present paper the data regarding fourth and eighth heating's have been given. The surface morphology of the particles synthesized was examined by SEM for all the samples.

Keywords: Nano Copper Meta Material Physical Parameters SEM, Applications.

\section{INTRODUCTION}

In recent decades nano technology has attracted scientists from many different areas. The fundamentals of nano technology in the fact that the properties of several materials change dramatically when their size is reduced to nano meter scale[ 1,2] The behavior of material changes between two distinct domains and nanometer range is considered as the threshold for the transition of a material's behavior. The metal nano particles due to their special properties find very important in optical, magnetic, thermal, catalysis, sensoric devices etc. Many metal nano particles are under active research due to interesting physical properties different from that of bulk face.[3]Due to the potentiality of copper oxide It acts as a catalyst whereas all metal oxides are not useful as catalyst. The unique property of copper oxide it acts as a semi conductor in various electronic devices, opto electronic devices such as electro chemical cell[4], gas sensor [5], magnetic storage devices[6], field emitters[7], High Tc super conductors[8], nano fluid [9].

\section{EXPERIMENTAL DETAILS}

The nano $\mathrm{Cu}$ powders, crystals in the form of pure metals as well as alloys have been synthesised using ancient Indian vedic metallurgical techniques [Metallurgy]. The crystalline phase of copper particles has been synthesized and characterized by XRD \& SEM using $\mathrm{CuK} \alpha$ as radiation source. Various experiments have been carried out to find out important physical parameters. The values are given in tabular form. X-Ray diffraction data has been taken from an angle $2 \theta$ of $20^{\circ}$ to $70^{\circ}$ The complete analysis has been done for thermal and electrical conductivity. The Vicker hardness test has been tested similarly melting point and density parameters, copper purity test and oxidation layer thickness are conducted.

\section{RESULTS \& DISCUSSIONS}

The physical parameters measured are given in the tabular form:-

Table 1

\begin{tabular}{|l|l|l|}
\hline TEST & $4^{\text {th }}$ Heating & $8^{\text {th }}$ Heating \\
\hline $\mathrm{Cu}$ Purity Test & $99.98 \%$ & $99.96 \%$ \\
\hline Melting Point & $1082^{0} \mathrm{C}$ & $1081^{0} \mathrm{C}$ \\
\hline Density & $8.57 \mathrm{~g} / \mathrm{cc}$ & $8.49 \mathrm{~g} / \mathrm{cc}$ \\
\hline Viker Hardness & 82.2 & 80.8 \\
\hline Electrical Conductivity & $72 \%$ & $73 \%$ \\
\hline Cu Chemical Taste & $99.98 \%$ & $99.98 \%$ \\
\hline $\begin{array}{l}\text { Oxidation Layer } \\
\text { thicknees }\end{array}$ & $\begin{array}{l}150 \\
\text { microns } \\
\text { depth }\end{array}$ & $\begin{array}{l}150 \\
\text { microns } \\
\text { depth }\end{array}$ \\
\hline
\end{tabular}




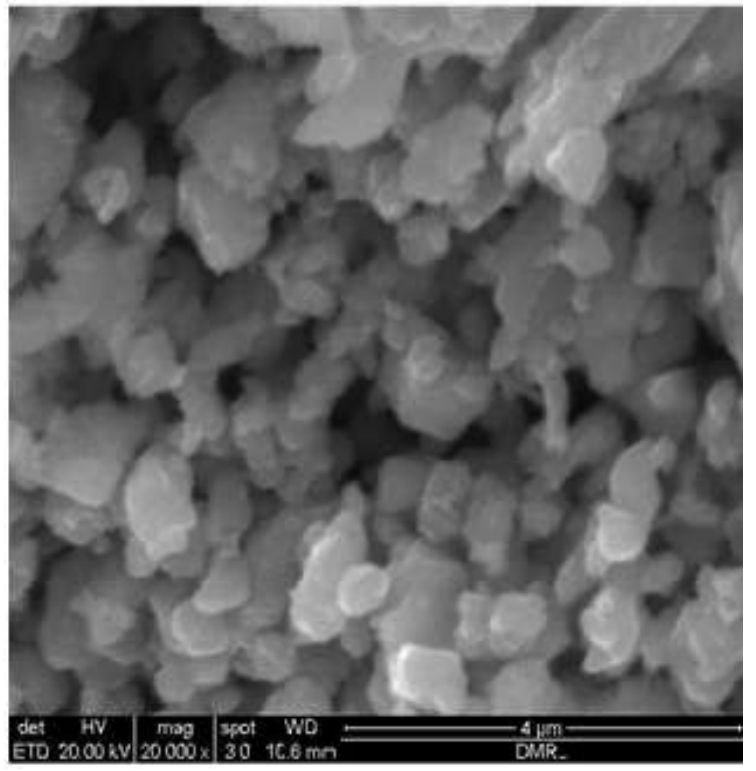

Fig 1

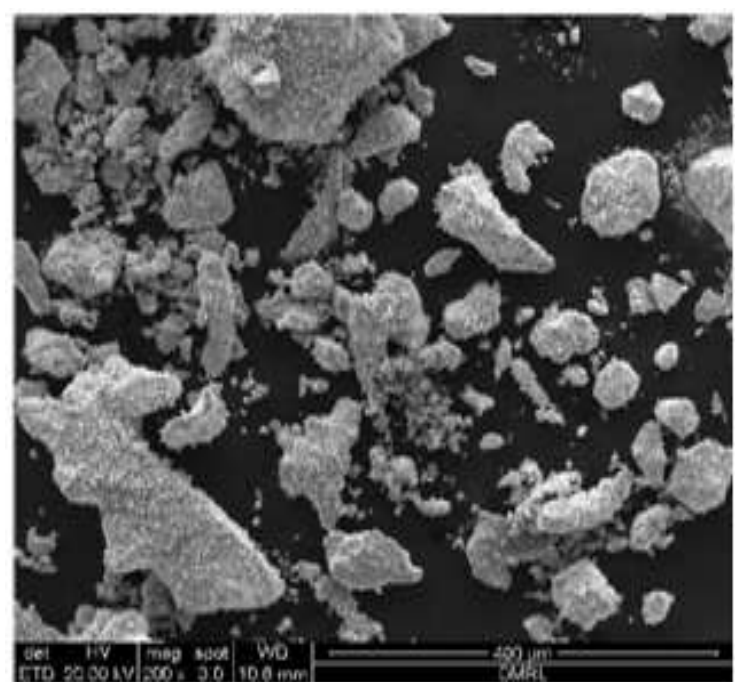

Fig 2

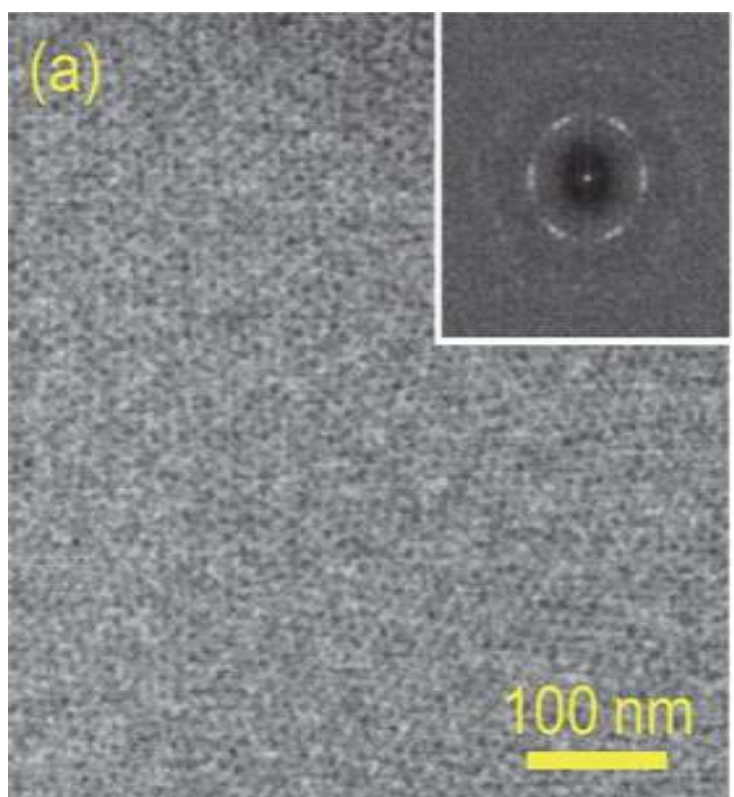

Fig 3

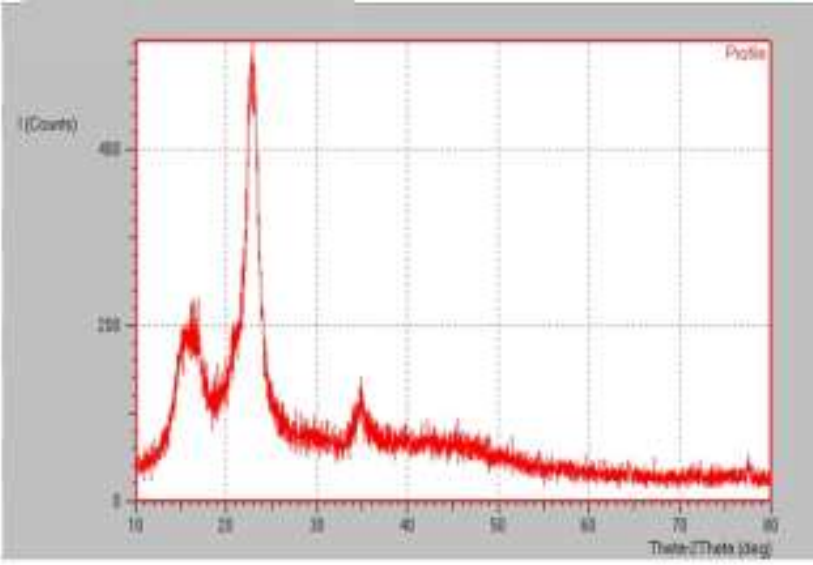

Fig 4

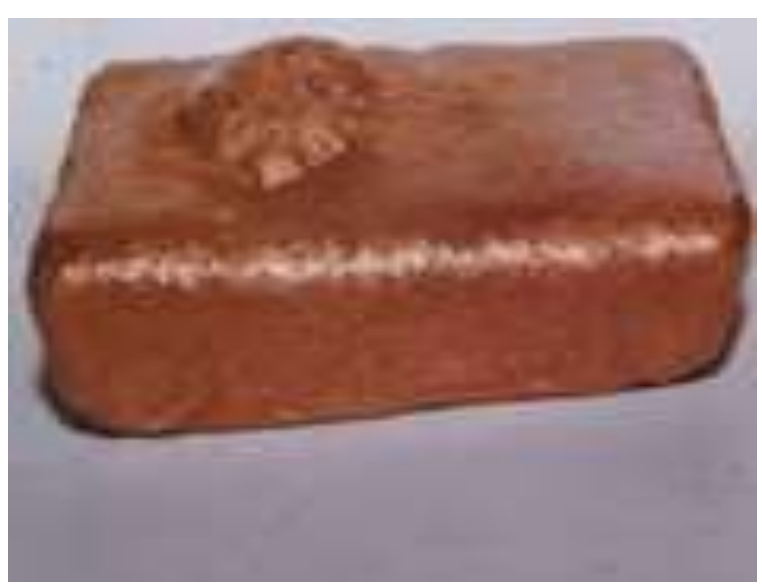

Fig 5

\section{Our research method}
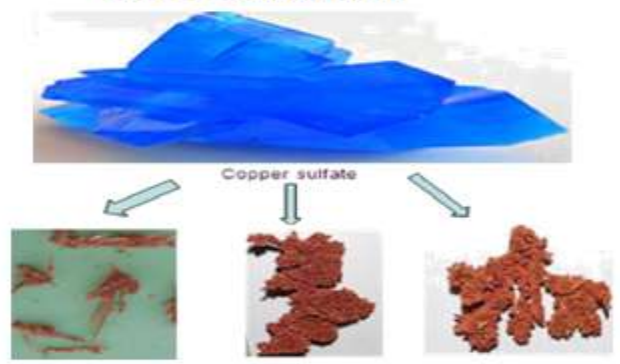

- step - 1 copper crystas form copper sulfote

\section{Our research method}

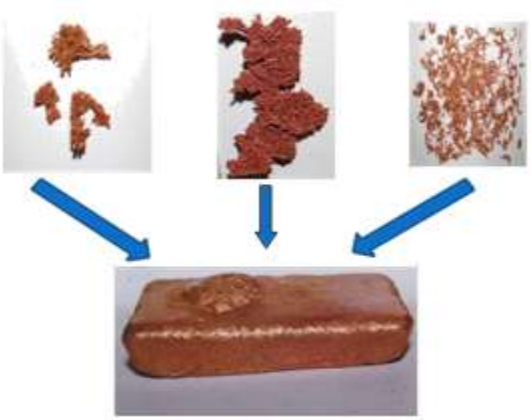

- step -2 melting these crystals for crystalline copper metal

- C -2101 kopu Thamra Loham (Nano crystalline copper metal) = copper metamaterial 


\section{Results}

The synthesis of nano copper exhibit single face parameters shown by $\mathrm{X}$ RD in the figure. SEM pictures exhibit that grain size is around $100 \mathrm{~nm}$. Results are showing very promising values under this metallurgical synthesis. Further efforts are put up to reduce the particle size and monitor to optimum conditions for fabricating new nano crystals. Fig 5 shows the highest density $8.70 \mathrm{~g} / \mathrm{cc}$ and all other samples are having the similar or density values from $8.5-8.7 \mathrm{~g} / \mathrm{cc}$.

\section{REFERENCES}

[1] D.P Chattopadhyay, Nanotechnology-the emerging trends, Textiles ,33(2006),21-24

[2] B.H Patel and D.P Chattopadhyay Nano particles and their uses in Textiles, The Indian Textile Journal,118(2007),23-31

[3] D.P Chattopadhyay and B.H Patel, improvement in physical and dyeing properties of natural fibres through pre-treatment with nano silver particles Indian Journal of fiber in textile research.34 (2009), 368-373.

[4] P.Poizot, S Laruelle,S.Grugeon, L Dupontl,J.M Tarascon, Nature 407,496(2000)

[5] V.R Katti,A.K Debnath, K.P Muthe,M Kaur, A.K Dua, S.C Gadkari, Sens actuators B.Chem, 245(2003)

[6] H.M Fan, L.T Yang, W.s Hua, X.F Wu, Z.Y Wu, S.S.Xie, Nano Technology, 15,37(2004)

[7] C.T Hsieh, J.M Chen, H,H Lin, H.C Shih, Appl Phys, Lett 83 3383(2003)

[8] M.K Wu, J.R Asburn, C.T Torng, P.hHor, R.L Meng, L. Gao Phys. Rev Lett 28,908(1987)

[9] M.H Chang, H.S Liu, C.T Tai, Powder Technology207,378(2011) 